\section{DIGITAL COMMONS \\ @ UNIVERSITY OF SOUTH FLORIDA}

\section{ABO: Interactive Journal for Women in the Arts, 1640-1830}

Volume 4

Issue 1 Volume 4.1 (Spring 2014)

Article 8

2014

\title{
Review of Enit Karafili Steiner, Jane Austen's Civilized Women: Morality, Gender, and the Civilizing Process
}

Sarah Raff

Pomona College, sarah.raff@pomona.edu

Follow this and additional works at: https://digitalcommons.usf.edu/abo

Part of the Dramatic Literature, Criticism and Theory Commons, Educational Methods Commons, Feminist, Gender, and Sexuality Studies Commons, and the Literature in English, British Isles Commons

\section{Recommended Citation}

Raff, Sarah (2014) "Review of Enit Karafili Steiner, Jane Austen's Civilized Women: Morality, Gender, and the Civilizing Process," ABO: Interactive Journal for Women in the Arts, 1640-1830: Vol.4: Iss.1, Article 8. http://dx.doi.org/10.5038/2157-7129.4.1.8

Available at: https://digitalcommons.usf.edu/abo/vol4/iss1/8

This Reviews is brought to you for free and open access by Digital Commons @ University of South Florida. It has been accepted for inclusion in ABO: Interactive Journal for Women in the Arts, 1640-1830 by an authorized administrator of Digital Commons @ University of South Florida. For more information, please contact digitalcommons@usf.edu. 
Review of Enit Karafili Steiner, Jane Austen's Civilized Women: Morality, Gender, and the Civilizing Process

\section{Keywords}

Jane Austen, Enit Karafili Steiner, Norbert Elias, The Civilizing Process

\section{Creative Commons License}

(c) $($ ) $\Theta$

This work is licensed under a Creative Commons Attribution-No Derivative Works 3.0 License. 
Enit Karafili Steiner. Jane Austen's Civilized Women: Morality, Gender, and the Civilizing Process. Gender and Genre 9. London: Pickering and Chatto, 2012. \$99.00. 228pp. Index. ISBN: 9781848931770.

Reviewed by Sarah Raff

Pomona College

Enit Karafili Steiner's ambitious book aims to connect Austen's fiction with three distinct types of thinkers: eighteenth-century social and philosophical commentators such as Mary Wollstonecraft, Hannah More, and John Millar; "postmodern" feminists such as Seyla Benhabib, Sandra Harding, and Carol Gilligan; and the sociologist Norbert Elias, whose book The Civilizing Process: Sociogenetic and Psychogenetic Investigations, first published in German in 1939, gives Steiner's study its title. The project is novel in method as well as scope. Austen criticism of recent decades has registered nearly every development in literary studies generally, but it tends to wear its theoretical influences so lightly that unalerted readers could miss them altogether. Steiner, by contrast, who teaches at the University of Zurich, devotes long passages of explanation to her chosen theorists, at least as much space as she allots to her readings of Austen, and thereby reflects a convention of the Swiss academy. If the results seem somewhat out of step with contemporary Austen scholarship, part of their interest derives from their bridging of European and Anglo-American intellectual communities. This study marches audaciously to the beat of an unfamiliar drum.

Steiner's central idea is that Austen rightly honors the individual's connections to his or her social environment. Arguing against those critics who, she claims, use Austen's "attention to the communal" to deny Austen's "progressive qualities," Steiner finds that Austen's works reflect the progressive notion that "to be civilized means to be aware [of] and reflect upon one's situatedness and embeddedness, allowing this knowledge to inform one's judgment and way of life" $(184,185)$. This awareness is sometimes, in Steiner's reading, a final achievement of Austen's heroines, sometimes a feature of the fictions that contain them. In an opening chapter, Steiner suggests that, much as human social groups proceed, according to Elias, through three stages of development, "courtoisie, civilité, and civilization," so does the path of Austen's juvenile writing (35). The transition from the earliest sketches of the juvenilia to the later pieces demonstrates "a shift from physical to verbal violence, from open to more restrained human aggressiveness" (35). Drawing on Sandra Harding's "standpoint theory,", the following chapter traces from the unpublished epistolary novella Lady Susan to Northanger Abbey a similar evolution, over the course of which "the female psychological habitus undergoes a shift from social constraint to self-constraint" (47). Here Steiner joins a number of other critics who are turning attention to the superb, long-neglected Lady Susan and comparing it with Pierre Choderlos de Laclos's Les Liaisons Dangereuses. Steiner is, I believe, the first to point out that while Laclos's libertine female protagonist, Madame de Merteuil, survives in society by keeping the secret of her promiscuity carefully guarded, Lady Susan Vernon is able to rely on her "immediate influence over people" to "deconstruct whatever truths or lies may have been told about her and replace them with the truths or lies of her choice" (53). A further chapter concerning the way Sense and Sensibility and Pride and Prejudice "wrestle with the question of otherness," the former in its treatment of two sisters, the latter in the courtship plot of Elizabeth Bennet and Mr. Darcy, completes the first half of the book (75). 
Steiner's enterprising theoretical reach sets certain challenges of exposition: those of elucidating a given theory and of making the audience care to learn about it. Readers unfamiliar with the work of Elias, Benhabib, Harding, Marcia Cavell, or Millar will not come away from Steiner's book feeling much the wiser and may well have trouble tracking what is said of these thinkers. There are diverse, sometimes competing, technical languages deployed here, and the result can be cacophonous. One often has occasion to wish that Steiner, who has won a prize for her translation of Austen's Pride and Prejudice into Albanian, had had the benefit of an editor who could have rendered her English more consistently idiomatic. Numerous usage errors (Mr. Knightley, "who thanks his own wedding to the unexpected opportunity opened by a poultry robbery") and lapses in copyediting (Mr. Darcy's aunt is "Lady de Burgh") contribute to obscuring the argument $(145,35)$. In its knotty syntax and abstraction, this sentence is quite typical: "My central contention is that, viewing Austen's fiction from these different perspectives, we realize that when she insists on an ongoing sociability which unfolds first in domestic settings and permeates the public realm as well as on the impact of embodied socialization, introspection and self-monitoring, far more is at stake than a proper lady's keen sense of decorum" (1-2). Elias's ideas are not quaint but sometimes sound that way in Steiner's rendering. Praising "civilization," with the "self-monitoring" of those who have attained it, as a clear-cut good, Steiner arguably misrepresents Elias's descriptive theory as a normative claim. Yet in its passages of concrete textual analysis, especially, this study has much to offer.

The second half of the book, which devotes a chapter to each of Austen's last-conceived novels, is the strongest. In a shrewd reading of Mansfield Park, Steiner cites the cutting remark that Sir Thomas Bertram delivers to Fanny Price as he leaves for Antigua and refreshingly thinks to ask exactly "what kind of improvement" in Fanny "would have answered Sir Thomas's hopes" (113). Her solution, namely that Sir Thomas wishes Fanny to conform to the type to which Mary Crawford belongs, that of "the socially skilled female who pleases and accommodates a company through easy conversation," leads her to evocative reflections on shyness, which she thinks Austen treats not as "a matter of personal awkwardness, but" rather as "a result of powerlessness and dependence" $(115,119)$. In Steiner's reading, Mansfield Park "exposes the double standard of a practice that promotes backwardness, so as to turn it against its victim" (115). Steiner shows similar imaginative sympathy when, making effective use of trauma theory to show how Fanny Price's visit to her family in Portsmouth represents a missed opportunity for "the stitching together of" a fragmented sense of self and "a life story," she lists some of the questions that Mrs. Price neglects to pose to her long-absent daughter (124). The following chapter presents a sharp analysis of the "unusual mixture" in Emma Woodhouse "of independence and confinement, self-indulgence and privation, egocentricity and empathy" (129). With illuminating comments on the limits of Emma's power at Hartfield,Steiner finds that Emma's denouement shows the heroine working toward "the formation of a civilized habitus" that balances the claims of self and society (136). In a final chapter on Persuasion that stands in tacit disagreement with much previous commentary on that novel, Steiner intriguingly finds in Anne Elliot and in women generally the very same untaught resiliency that Anne identifies in her old school friend Mrs. Smith. Although this reading would profit from a more direct confrontation with obvious counterarguments, it displays once again an astute and humane critical intelligence at work. 